\title{
Apatite fission track implications for timing of hydrothermal fluid flow in Tertiary volcanics of the Bohemian Massif
}

\author{
Jiří FILIP1*, Jaromír ULRYCH ${ }^{1}$, Jiří ADAMOVIČ¹, Kadosa BALOGH² \\ ${ }^{1}$ Institute of Geology, Academy of Sciences of the Czech Republic, v.v.i., Rozvojová 269, 16502 Prague 6, Czech Republic; \\ filip@gli.cas.cz \\ ${ }^{2}$ Institute of Nuclear Research, Hungarian Academy of Sciences, P.O. Box 51, H-4001 Debrecen, Hungary \\ ${ }^{*}$ Corresponding author
}

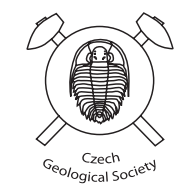

\begin{abstract}
Late Cretaceous to Palaeogene subvolcanic/volcanic rocks from the Bohemian Massif were subjected to apatite fission track (AFT) and K-Ar dating. Striking discrepancies between the AFT and K-Ar ages encountered in most samples cannot be explained by slow cooling rates because of the small sizes and shallow emplacement depths of the subvolcanic bodies. Instead, apatites from these rocks are believed to have re-entered the total annealing zone during episodes of hydrothermal fluid activation along major faults and dyke contacts. The presence of two such thermal disturbances can be inferred from the available data in the Late Oligocene (28 to $26 \mathrm{Ma}$ ) and the Early Miocene (20 to $16 \mathrm{Ma})$ times. The older episode is manifested in the Ohře/Eger Rift region and in the Elbe Zone, while the younger seems to be limited to the former area only. The distribution of the regions with the increased hydrothermal fluid flow was controlled by the crustal weaknesses, the presence of magmatic centres and by the regional tectonic stress field.
\end{abstract}

Keywords: Bohemian Massif, fission tracks, apatite, $K$-Ar dating, volcanic rocks, thermal events, stress field Received: 16 August 2007; accepted 11 December 2007; handling editor: E. Jelinek

\section{Introduction}

Problems with precise and geologically reliable dating of Cenozoic volcanism in Central Europe persist due to alteration and the presence of excess $\mathrm{Ar}$ in rock samples (Balogh et al. 2005). In the Bohemian Massif, the presence of the excess Ar was proven especially in sodalite and nepheline-rich rocks of phonolitic composition from the Roztoky Intrusive Centre (Ulrych et al. 2006). With the aim of a further refinement of K-Ar chronometry, eight samples of unaltered volcanic rocks of known radiometric ages were also subjected to apatite fission track dating. Surprisingly, most samples yielded apatite fission track ages much younger compared to their K-Ar ages. The wide discrepancies between the ages obtained cannot be explained by slow cooling rates or other factors imposed by the different methodology and should be therefore attributed to post-emplacement re-heating of the rocks to temperatures well below the closure temperature of the K-Ar system but sufficient for resetting the apatite fission track chronometer. In this paper, processes responsible for such re-heating are interpreted in terms of hydrothermal fluid activation along faults pertaining to the Ohře/Eger Rift and the Elbe Zone.

\section{Geological setting}

Cenozoic volcanism of the Bohemian Massif (Fig. 1) concentrates mostly to the Ohře/Eger Rift (Doupovské hory and České středohoří Mountains) and belongs to the anorogenic intraplate alkaline volcanism of the Central European Volcanic Province - CEVP (sensu Wimmenauer 1974; Ziegler 1982; Wilson and Downes 1991). The NE-SW-elongated Ohře/Eger Rift is an integral part of the European Cenozoic Rift System - ECRIS (Dèzes et al. 2004) and was formed in response to the collision of the Alpine orogen with the Bohemian Massif in the foreland (Ziegler et al. 1995; Dèzes et al. 2004). In the central part of the České středohoři Mts., the Ohře Rift transects the NW-SE-striking Elbe Zone, a swarm of faults reactivated in the Cenozoic times within the trans-European Elbe Fault System (Scheck et al. 2002).

The age distribution of volcanism in the Bohemian Massif determined from a set of $250 \mathrm{~K}-\mathrm{Ar}$ measurements spans an interval of 79-0.26 Ma (Ulrych et al. 1999). There is a coherent distribution of volcanic activity with partly separated Late Cretaceous to Palaeocene and PlioPleistocene episodes. Peak volcanic activity dates to the Oligocene to Early Miocene (c. 35 to $20 \mathrm{Ma}$ ). Ulrych and Pivec (1997) recognized two main volcanic phases based on K-Ar data:

1. Pre-rift unimodal mafic Late Cretaceous to Early Eocene volcanism (79-51 Ma) restricted to the rift flanks, 2. Syn-rift major bimodal volcanic phase with (i) the Mid Eocene to Mid Miocene (42-16 Ma) and (ii) Late Miocene episodes (19-4 Ma).

Four lithostratigraphic units were recognized in the central part of the volcanic complex of the České 


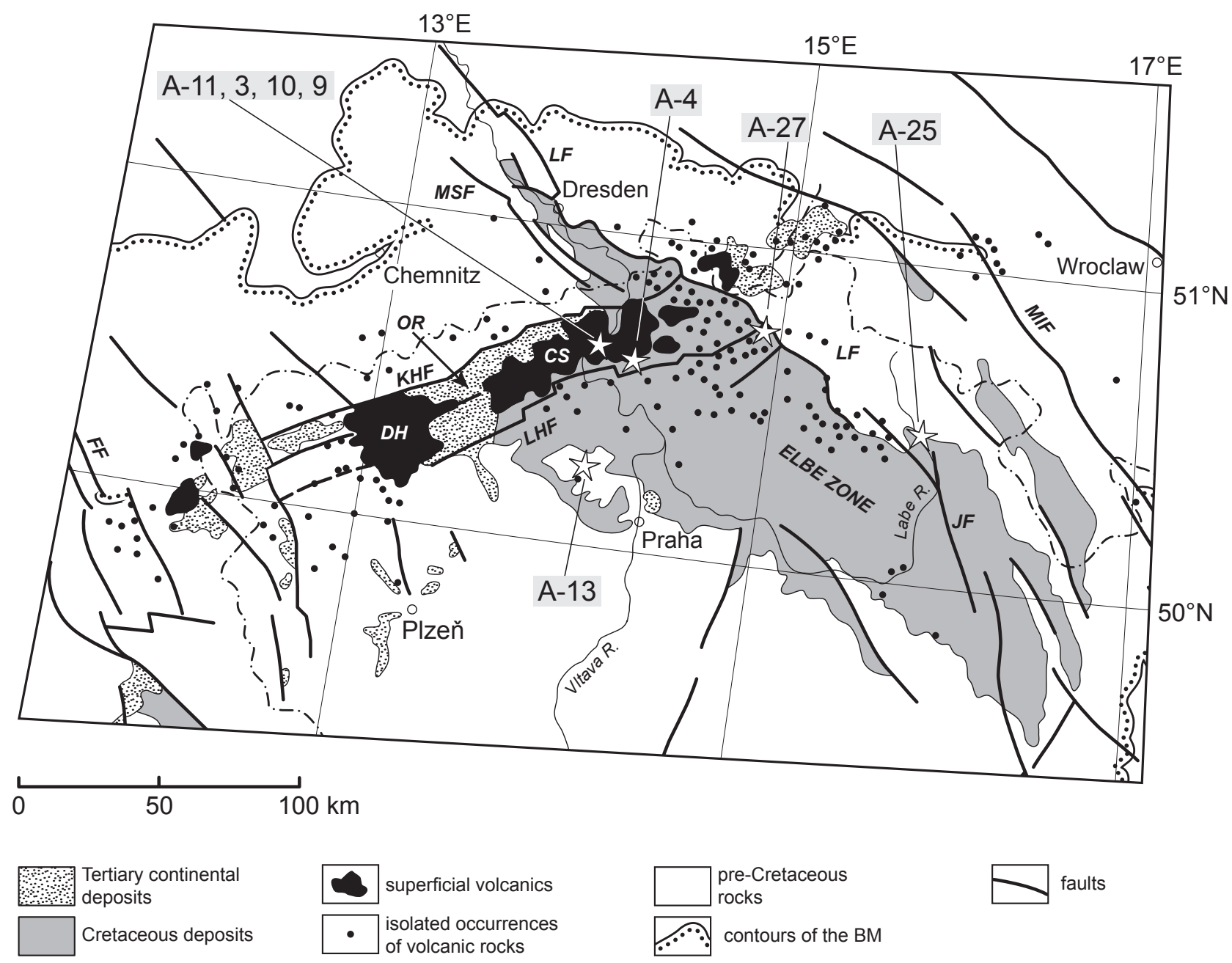

Fig. 1 A simplified geological map of the northern Bohemian Massif with sampling sites. FF - Franconian Fault, KHF - Krušné hory Mts. Fault, LDF - Litoměřice Deep Fault, MSF - Middle Saxonian Fault, LF - Lusatian Fault, MIF - Main Intrasudetic Fault, JF - Jivina Fault, DH - Doupovské hory Mts., CS - České středohoří Mts.

středohoří Mts. in the NE part of the Ohře Rift by Cajz et al. (1999):

1. Ústí Formation (36.1-25.5 Ma) - lavas and volcaniclastics of primitive basanitic composition.

2. Děčín Formation (30.8-24.7 Ma) - lavas and pyroclastics of trachybasaltic character including subvolcanics of the Roztoky Intrusive Centre (33.1-25.6 Ma, see Ulrych and Balogh 2000).

3. Dobrná Formation (24.0-19.3 Ma) - lava flow of primitive basanitic composition.

4. Štrbice Formation (13.9-9.0 Ma) - intrusives and effusives of basanitic composition.

Unfortunately, the K-Ar ages of the first three units broadly overlap.

In the Elbe Zone, three rock associations were distinguished by Ulrych et al. (1999) based on their geochronological constraints:
1. Olivine clinopyroxenite - alkali clinopyroxenite intrusive association represented by the Dvưr Králové nad Labem Volcanic Centre, eastern Bohemia (69 Ma; Ulrych et al. 1996). A similar melilite lamprophyre - olivine melilitite - olivine nephelinite series with hypabyssal olivine melilitolite of the Osečná Complex (79-51 Ma; Pivec et al. 1998a) is located at an intersection of the Elbe Zone and the Ohře Rift. Both occurrences are associated with the Lusatian Fault Zone and its continuation to the east.

2. A bimodal olivine-poor nephelinite - phonolite series (36-21 Ma) characteristically developed in central Bohemia, e.g. Říp Hill 25.6 Ma (Ulrych et al. 1998), Vinařická hora Hill 31.0-25.5 Ma (Ǩanda et al. 2003) and Slánská hora Hill 30.1 Ma (this paper).

3. A picrite - basanite - olivine nephelinite association connected with the Lusatian Fault in NE Bohemia 
(Kozákov volcano group 6.6-4.0 Ma and Útěchovický Špičák Hill near Hamr na Jezeře 7 Ma; Ulrych et al. 1999).

\section{Samples and methods}

\subsection{Sample preparation and analytical tech- niques}

Rock samples for the study of fission tracks in apatites (see Tab. 1, Fig. 1) were acquired mostly in the central part of the České středohoří Mts. in the Roztoky Intrusive Centre. They represent subvolcanic monzodiorite of the centre (A-11), hornblendite cumulate in sodalite syenites
(A-9), lamprophyre camptonite (A-10) and trachytic breccia of the centre (A-3). Sample A-4 comes from a tephrite lava flow. Samples A-25 and A-27 represent the Dvưr Králové nad Labem and the Osečná complexes, respectively, both occurring in the proximity of significant faults of the Lusatian Fault Zone. Sample A-13 comes from Slánská hora Hill in Central Bohemia, positioned on a significant NW-SE-striking fault zone.

The samples showed no visible signs of alteration, and this was confirmed by the very low $\mathrm{H}_{2} \mathrm{O}^{-}$and $\mathrm{CO}_{2}$ contents. With the exception of $\mathrm{A}-13$ and $\mathrm{A}-27$, all samples were characterized by $\mathrm{P}_{2} \mathrm{O}_{5}$ contents appropriate to the given rock type (Ulrych et al. 1999). Nephelinite sample A-13 contained 5.07 wt. $\% \mathrm{P}_{2} \mathrm{O}_{5}$ (Novák and Matějka

Tab. 1 Geological and petrographic characteristics of the studied rock samples

\begin{tabular}{|c|c|c|c|c|c|}
\hline $\begin{array}{l}\text { Sample } \\
\text { No. }\end{array}$ & Locality & $\begin{array}{l}\text { Geographic } \\
\text { coordinates* } \\
\text { Lat. } \\
\text { Long. }\end{array}$ & Geological situation & Rock & $\begin{array}{l}\text { Apatite } \\
\text { content } \\
\text { (vol. \%) }\end{array}$ \\
\hline A-11 & Roztoky near Ústí nad Labem & $\begin{array}{l}50^{\circ} 41^{\prime} 14^{\prime \prime} \mathrm{N} \\
14^{\circ} 11^{\prime} \quad 3^{\prime \prime} \mathrm{E}\end{array}$ & $\begin{array}{l}\text { Tectonically delimited subvolcanic elliptical } \\
\text { section of the monzodiorite stock } 500 \mathrm{~m} \text { in } \\
\text { diameter in the Roztoky Intrusive Centre of the } \\
\text { České středohoří Mts. with geochemical affinity } \\
\text { to the volcanics of the Děčín Fm. }\end{array}$ & $\begin{array}{l}\text { Monzodiorite } \\
\text { (inhomogeneous } \\
\text { intrusion often vertically } \\
\text { banded) }\end{array}$ & 1 \\
\hline A-3 & Skrytín near Roztoky & $\begin{array}{l}50^{\circ} 41^{\prime} 57^{\prime \prime} \mathrm{N} \\
14^{\circ} 11^{\prime} \quad 8^{\prime \prime} \mathrm{E}\end{array}$ & $\begin{array}{l}\text { Elliptical crater vent ( } 3 \text { by } 1.5 \mathrm{~km} \text { ) filled with } \\
\text { trachytic breccia and bounded by blocks of } \\
\text { contact-metamorphosed Upper Cretaceous } \\
\text { marlstones in the NE, forming the central part } \\
\text { of the Roztoky Intrusive Centre of the České } \\
\text { středohoří Mts. Younger phonolites and trachytes } \\
\text { intruded the breccia. }\end{array}$ & $\begin{array}{l}\text { Trachytic breccia } \\
\text { with xenoliths of } \\
\text { Saxothuringian } \\
\text { crystalline rocks, } \\
\text { Tertiary volcanics and } \\
\text { Cretaceous sediments }\end{array}$ & 1 \\
\hline A-10 & Dobkovice near Děčín & $\begin{array}{l}50^{\circ} 42^{\prime} 37^{\prime \prime} \mathrm{N} \\
14^{\circ} 11^{\prime} 33^{\prime \prime} \mathrm{E}\end{array}$ & $\begin{array}{l}\text { A dyke ( } 30 \mathrm{~cm} \text { thick) of camptonite penetrating an } \\
\text { older olivine nephelinite intrusion of the Roztoky } \\
\text { Intrusive Centre pertaining to the Ústí Fm. }\end{array}$ & $\begin{array}{l}\text { Camptonite } \\
\text { (relatively } \\
\text { homogeneous) }\end{array}$ & 1 \\
\hline A-9 & Zubrnice near Malé Březno & $\begin{array}{l}50^{\circ} 38^{\prime} 55^{\prime \prime} \mathrm{N} \\
14^{\circ} 12^{\prime} 41^{\prime \prime} \mathrm{E}\end{array}$ & $\begin{array}{l}\text { Inhomogeneous elliptical intrusion ( } 500 \text { by } \\
250 \mathrm{~m} \text { ) of sodalite syenite at "Giegelberg" with } \\
\text { numerous cumulates of hornblendite passing to } \\
\text { hornblende gabbros and of clinopyroxenite (up to } \\
0.25 \mathrm{~m}^{3} \text { ) in some vertically oriented zones up to } \\
40 \text { vol. \% with geochemical affinity to the Děčín } \\
\text { Fm. of the České středohoří Mts. }\end{array}$ & $\begin{array}{l}\text { Hornblendite xenolith } \\
(15 \text { by } 8 \mathrm{~cm}) \text { in sodalite } \\
\text { syenite }\end{array}$ & 4 \\
\hline A-4 & Dubičná near Úštěk & $\begin{array}{l}50^{\circ} 36^{\prime} 59^{\prime \prime} \mathrm{N} \\
14^{\circ} 22^{\prime} 10^{\prime \prime} \mathrm{E}\end{array}$ & $\begin{array}{l}\text { A tephrite lava flow. Characteristic locality of the } \\
\text { Děčín Fm. in the neighbourhood }(1 \mathrm{~km}) \text { of the } \\
\text { Litoměřice Deep Fault, České středohoři Mts. }\end{array}$ & Tephrite (homogeneous) & 1 \\
\hline A-13 & Slánská hora Hill in Slaný & $\begin{array}{l}50^{\circ} 13^{\prime} 54^{\prime \prime} \mathrm{N} \\
14^{\circ} 5^{\prime} 45^{\prime \prime} \mathrm{E}\end{array}$ & $\begin{array}{l}\text { A conduit of nephelinite intrusion(?) in the Elbe } \\
\text { Zone in Central Bohemia intruded by a younger } \\
\text { dyke of nephelinite composition. }\end{array}$ & $\begin{array}{l}\text { Nephelinite } \\
\text { (homogeneous) }\end{array}$ & 5 \\
\hline A-27 & Osečná near Stráž pod Ralskem & $\begin{array}{l}50^{\circ} 41^{\prime} 44^{\prime \prime} \mathrm{N} \\
14^{\circ} 55^{\prime} 46^{\prime \prime} \mathrm{E}\end{array}$ & $\begin{array}{l}\text { Lopolith-like (sill) layered intrusion of olivine } \\
\text { melilitolite occupying an area of } 12.5 \mathrm{~km}^{2} \text { with an } \\
\text { apparent thickness of } 20 \text { to } 60 \mathrm{~m} \text { at the junction of } \\
\text { the Stráž (a part of the Litoměřice Deep Fault) and } \\
\text { the Lusatian faults of the Elbe Zone. }\end{array}$ & $\begin{array}{l}\text { Pegmatoid in olivine } \\
\text { melilitolite (drill core), } \\
\text { depth c. } 200 \mathrm{~m} \text { (in Upper } \\
\text { Cretaceous sediments) }\end{array}$ & 4 \\
\hline$A-25$ & $\begin{array}{l}\text { Les Království Reservoir near } \\
\text { Dvůr Králové nad Labem }\end{array}$ & $\begin{array}{l}50^{\circ} 27^{\prime} 31^{\prime \prime} \mathrm{N} \\
15^{\circ} 46^{\prime} \quad 8^{\prime \prime} \mathrm{E}\end{array}$ & $\begin{array}{l}\text { A sill of inhomogeneous pyroxenite occupying an } \\
\text { area of over } 6.9 \mathrm{~km}^{2} \text { with the max. thickness of } \\
10 \text { to } 15 \mathrm{~m} \text { from the neighbourhood of a feeding } \\
\text { channel situated at a junction of the Zvičina Fault } \\
\text { in continuation of the Lusatian Fault and the local } \\
\text { W-E striking fault in the Elbe Zone. }\end{array}$ & $\begin{array}{l}\text { Pegmatoid in alkali } \\
\text { pyroxenite } \\
\text { (drill core), depth } \\
\text { c. } 60 \mathrm{~m} \text { (in Upper } \\
\text { Cretaceous sediments) }\end{array}$ & 3 \\
\hline
\end{tabular}

\footnotetext{
* Geographic coordinates are in the system WGS 84
} 
1999) and olivine melilitolite sample A-27 4.23 wt. \% $\mathrm{P}_{2} \mathrm{O}_{5}$ (new data).

Apatite concentrates were obtained using shaking table, heavy liquid and magnetic separation techniques. Apatite concentrates were carefully washed in acetic acid to achieve apatite free of carbonate. Finally, the concentrates were upgraded by hand picking.

The apatites were studied microscopically in the transmitted light in thin-sections and reflected light in concentrates embedded in polished epoxy mounts. The mineral analyses were carried out using the JXA-50A microprobe with spectrometer EDAX PV 9400 at the Institute of Geology AS CR in Prague. The equipment was operated in compound standard mode with apatites from Opalice and Ulan Dryk as standards, and ZAF correction method was applied. Experimental conditions involved an accelerating voltage of $20 \mathrm{kV}$, beam currents of $1.5 \mathrm{nA}$, a beam diameter of $0.5 \mu \mathrm{m}$ and a counting time of $120 \mathrm{~s}$ per analysis. The standards employed were of synthetic $\left(\mathrm{SiO}_{2}, \mathrm{TiO}_{2}, \mathrm{Al}_{2} \mathrm{O}_{3}, \mathrm{Fe}_{2} \mathrm{O}_{3}\right.$, and $\left.\mathrm{MgO}\right)$ and natural origin (e.g., jadeite, apatite, leucite, diopside, spinel [all $\mathrm{K} \alpha$ ], and barite $[\mathrm{L} \alpha]$ for $\mathrm{Ba}$ ).

Approximately $100 \mathrm{mg}$ each of the apatite concentrates was finely ground and $\mathrm{CO}_{2}$ contents determined by coulometric alkalimetric titration (Sixta 1977) using Coulomat CS 701. Data precision was about $3 \%$ relative.

\subsection{K-Ar dating}

The K-Ar isotope measurements of the parental rocks bearing apatites were carried out on whole-rock samples and/or monomineralic amphibole fraction. The K-Ar ages were measured with the conventional techniques using ${ }^{38} \mathrm{Ar}$ spike and emission flame photometry at the Institute of Nuclear Research of the Hungarian Academy of Sciences (ATOMKI), Debrecen. Interlaboratory standards Asia 1/65, HD-B1 and LP-6 as well as atmospheric Ar were used for checking and calibration of the age determinations. Details on the instruments, the applied methods and results of calibration were described by Odin et al. (1982), Balogh (1985) as well as Ulrych and Balogh (2000).

The presence of excess Ar has been demonstrated for some Cenozoic volcanics of the Bohemian Massif (Ulrych et al. 2006) but it has been also proven that the real geological age can be obtained by independent dating of two or more minerals from the same sample. An opposite effect has been also observed: leucite- and nepheline-bearing rocks may yield $\mathrm{K}-\mathrm{Ar}$ ages reduced by even 30-40\% due to the loss of radiogenic Ar if the Ar extraction line is baked at the usual temperature (about $250{ }^{\circ} \mathrm{C}$ ) during its evacuation before degassing the rock (Balogh et al. 2005). This effect may be explained by a still unspecified submicroscopic structure of nepheline and/or leucite, which can be fortunately easily recognized and avoided. Therefore, several mineral phases were analysed from our samples, where possible.

\subsection{Apatite Fission Track (AFT) chronometry}

In apatite crystals with trace amounts of uranium, linear disordered regions of crystal lattice are formed by fragments ejected during spontaneous nuclear fission of ${ }^{238} \mathrm{U}$. These regions named fission tracks can be enlarged by chemical etching and are countable using an optical microscope. The Apatite Fission Track (AFT) dating is based on counting the number of fission tracks that have accumulated since the last cooling of the crystal under its closure temperature. For apatites, the closure temperature for track retention is estimated to be $100 \pm 20$ ${ }^{\circ} \mathrm{C}$ at geologically realistic cooling rates of $1-10{ }^{\circ} \mathrm{C} / \mathrm{Ma}$ (Gleadow et al. 1986). For age calculation it is necessary to determine uranium $\left({ }^{238} \mathrm{U}\right)$ contents in apatites. This is achieved by irradiation of apatites by thermal neutrons in nuclear reactor and counting the tracks produced by the induced fission in muscovite external detector. The fission track age is then calculated from the ratio of spontaneous and induced track densities (Wagner and Van den haute 1992).

The external detector method (Wagner and Van den haute 1992; Filip 2001) was used for AFT dating of the Czech samples. Apatite grains were mounted in Epofix resin, polished and etched in $2.5 \% \mathrm{HNO}_{3}$ for 70 seconds to reveal the fission tracks. Low-uranium muscovite detectors (Jahre GmbH Wilhelmshaven, Germany) were fastened to the polished surfaces and stacked in irradiation cassettes with CN5 glass neutron detectors. The cassettes were irradiated by thermal neutrons in two irradiation campaigns: the first set of samples in the Thetis reactor, Institute for Nuclear Sciences, Gent University, Belgium, and the second set in the experimental reactor, Institut für Radiochemie, TU München, Garching, Germany.

Densities and lengths of spontaneous and induced tracks were measured by an Axioplan 2 (Zeiss) microscope (magnification 1600×) equipped with AUTOSCAN $^{\mathrm{TM}}$ stage. Fission track ages were calculated using zeta calibration method after Hurford and Green (1982, 1983). Apatites from the Fish Canyon tuff, Durango and Mount Dromedary Intrusive Complex were used as age standards. The ages were determined using the TRACKKEY program, version 4.2.f (Dunkl 2002). Consistency of the counting data with the Poisson distribution was verified by the $\chi^{2}$ test. The samples were irradiated in two different reactors with three zeta determinations on each of them, and then repeatedly measured.

Thermal history of the rocks was not determined due to the very low numbers of confined tracks. Fission track data are summarized in Tab. 2. 


\section{Results}

\subsection{K-Ar dating}

The K-Ar datings used in this paper were obtained following the methods described above and were published by Pivec et al. (1998a), Ulrych and Balogh (2000), as well as Ulrych et al. (1996, 2002, 2006). They are based on identical samples/outcrops as the AFT datings. The only exception is the age of sample A-4 (Dubičná; Tab. 1), which is taken as analogous to the ages of other tephritic superficial products of the Děčín Formation (Ulrych et al. 2002). The K-Ar ages of the samples are compatible with the geological settings at the particular sites but cannot be tested against stratigraphic position because most of the bodies are intrusions. Samples A-25 and A-27 belong to the pre-rift phase of the unimodal volcanism, while the remaining ones belong to the synrift bimodal volcanic phase.

A weak loss of radiogenic Ar has been detected for the tinguaite dyke penetrating the trachyte breccia at Skrytín (sample A-3 in Tab. 2, coded as PH-3/1B in Ulrych et al. 2006). Dating of this rock after usual baking yielded an age of $27.4 \pm 1.1 \mathrm{Ma}$ (on whole-rock sample) and $27.6 \pm 1.1 \mathrm{Ma}$ (on a less magnetic concentrate with density lower than $\left.2.67 \mathrm{~g} / \mathrm{cm}^{3}\right)$. After baking at a reduced temperature (about $150{ }^{\circ} \mathrm{C}$ ) of the last concentrate ages of $28.5 \pm 1.3 \mathrm{Ma}$ and $28.8 \pm 1.3 \mathrm{Ma}$, giving an average of $28.6 \pm 1.1 \mathrm{Ma}$, were obtained. This effect has been described for the leucite-nepheline-bearing alkali basalt of Hegyestü, Balaton Highland, Hungary, by Balogh et al. (2005). However, an age of only $25.6 \pm 1.0 \mathrm{Ma}$ was

Tab. 2 Apatite fission-track data and K-Ar ages for Cenozoic volcanics from the Bohemian Massif

\begin{tabular}{|c|c|c|c|c|c|c|c|c|c|c|}
\hline $\begin{array}{c}\text { Sample } \\
\text { No. }\end{array}$ & $\begin{array}{c}\text { K-Ar age } \\
\text { (Ma) }( \pm 1 \sigma)\end{array}$ & Lithology & $\begin{array}{c}\text { Grains } \\
\mathbf{n}\end{array}$ & $\begin{array}{c}\text { Spontaneous } \\
\text { tracks } \\
\rho_{\mathrm{s}}\left(\mathrm{N}_{\mathrm{s}}\right) \\
\end{array}$ & $\begin{array}{c}\text { Induced } \\
\text { tracks } \\
\rho_{\mathrm{i}}\left(\mathrm{N}_{\mathrm{i}}\right)\end{array}$ & $\begin{array}{c}\text { Detector } \\
\rho_{d}\left(N_{d}\right)\end{array}$ & $\begin{array}{c}P\left(\chi^{2}\right) \\
\text { test } \\
(\%)\end{array}$ & $\begin{array}{c}\text { AFT age } \\
(\mathrm{Ma})( \pm 1 \sigma)\end{array}$ & $\begin{array}{c}\text { Confined } \\
\text { tracks }\end{array}$ & $\begin{array}{l}\text { Mean length } \\
(\mu \mathrm{m})( \pm 1 \sigma)\end{array}$ \\
\hline \multirow{2}{*}{ A-11 } & $30.8 \pm 1.3^{*}$ & \multirow[b]{2}{*}{ monzodiorite } & 25 & $0.76(112)$ & $1.03(153)$ & $1.64(1973)$ & 95.6 & $15.7 \pm 3.0^{\mathrm{a})}$ & 4 & \multirow[b]{2}{*}{$15.0 \pm 0.6$} \\
\hline & (amphibole) & & 19 & $1.06(131)$ & $3.61(447)$ & $4.85(5824)$ & 97.6 & $19.9 \pm 2.3^{\mathrm{b})}$ & - & \\
\hline \multirow{4}{*}{ A-3 } & $28.6 \pm 1.1^{*}$ & \multirow{4}{*}{$\begin{array}{l}\text { trachyte } \\
\text { breccia }\end{array}$} & & & & & & & & \\
\hline & (whole rock) & & 12 & $2.48(173)$ & 2.77 (193) & $1.64(1973)$ & $<1$ & $19.2 \pm 3.5^{\text {a) }}$ & 7 & $14.1 \pm 1.7$ \\
\hline & $\begin{array}{l}\text { tinguaite dyke } \\
\text { penetrating }\end{array}$ & & 35 & $7.9(1712)$ & 23.58 (5099) & $4.85(5824)$ & $<1$ & $22.8 \pm 1.4^{b)}$ & 7 & $13.2 \pm 2.5$ \\
\hline & trachyte breccia & & & & & & & & & \\
\hline A-10 & $\begin{array}{c}28.2 \pm 0.9^{*} \\
\text { (whole rock) }\end{array}$ & camptonite & 20 & $0.68(68)$ & $0.55(55)$ & $1.64(1973$ & 99.7 & $26.5 \pm 6.2^{\text {a) }}$ & - & - \\
\hline \multirow{3}{*}{ A-9 } & \multirow{3}{*}{$\begin{array}{c}30.8 \pm 1.2^{*} \\
\text { (whole rock) }\end{array}$} & hornblendite & 25 & $1.36(204)$ & $1.44(216)$ & $1.64(1973)$ & 38.7 & $20.3 \pm 3.6^{a)}$ & 4 & $16.0 \pm 1.2$ \\
\hline & & xenolith in & 21 & $1.62(204)$ & $7.69(970)$ & $6.40(7684)$ & 48.9 & $18.8 \pm 1.8^{b)}$ & - & - \\
\hline & & sodalite syenite & 25 & $1.00(226)$ & $3.75(845)$ & $6.15(7388)$ & 39.6 & $23.0 \pm 2.1^{\mathrm{b})}$ & - & - \\
\hline A-4 & $\begin{array}{c}26.6-27.4 \pm 1.2^{* *} \\
\text { (whole rock) } \\
\text { tephrites of the }\end{array}$ & tephrite & 26 & $5.11(758)$ & $18.94(2808)$ & $7.55(9064)$ & $<1$ & $28.5 \pm 1.9^{b)}$ & 9 & $14.6 \pm 1.3$ \\
\hline & Děčín Fm. & & & & & & & & & \\
\hline \multirow{2}{*}{ A-13 } & $30.1 \pm 1.7^{+}$ & \multirow{2}{*}{ nephelinite } & 11 & 7.55 (499) & $9.75(644)$ & 1.64 (1973) & $<1$ & $16.6 \pm 2.6^{\mathrm{a})}$ & 11 & $15.1 \pm 0.9$ \\
\hline & (whole rock) & & 6 & 3.99 (168) & $15.44(649)$ & $4.85(5824)$ & $<1$ & $17.6 \pm 1.8^{b)}$ & - & - \\
\hline \multirow{3}{*}{ A-27 } & \multirow{3}{*}{$\begin{array}{l}64.1 \pm 3.0^{++} \\
\text {(whole rock) }\end{array}$} & \multirow{3}{*}{$\begin{array}{c}\text { olivine } \\
\text { melilitolite } \\
\text { with pegmatoid } \\
\text { pods }\end{array}$} & 15 & $0.74(67)$ & $0.59(53)$ & $1.64(1973)$ & 93.7 & $27.1 \pm 6.4^{\text {a) }}$ & 1 & 13.3 \\
\hline & & & 16 & $0.78(112)$ & $2.97(428)$ & $7.55(9064)$ & 99.4 & $27.6 \pm 2.3^{b)}$ & 7 & $15.2 \pm 0.7$ \\
\hline & & & 21 & 0.67 (164) & $2.15(530)$ & $6.15(7388)$ & 95.8 & $26.6 \pm 2.8^{b)}$ & 10 & $12.5 \pm 3.2$ \\
\hline$A-25$ & $\begin{array}{l}69.0 \pm 4.0^{+++} \\
(\text {whole rock) }\end{array}$ & $\begin{array}{c}\text { clinopyroxenite } \\
\text { with pegmatoid } \\
\text { pods }\end{array}$ & 21 & $0.78(99)$ & $0.65(82)$ & $1.64(1973)$ & 94.6 & $25.9 \pm 5.4^{\text {a) }}$ & 2 & $14.6 \pm 0.8$ \\
\hline
\end{tabular}

Sources for $K$-Ar ages

"Ulrych and Balogh (2000); ${ }^{* *}$ Ulrych et al. (2002); ${ }^{+}$Balogh (new data); ${ }^{++}$Ulrych et al. (in print); ${ }^{++}$Ulrych et al. (1996)

Description of samples used for fission track analysis, summary of track count data, pooled ages and lengths of confined tracks

$\mathbf{n}$ : number of counted apatite grains, $\boldsymbol{\rho}_{\mathbf{s}}=$ density of spontaneous tracks $\left(\times 10^{5} / \mathrm{cm}^{2}\right), \mathbf{N}_{\mathbf{s}}=$ number of spontaneous tracks, $\boldsymbol{\rho}_{\mathbf{i}}=$ density of induced tracks $\left(\times 10^{5} / \mathrm{cm}^{2}\right), \mathbf{N}_{\mathrm{i}}=$ number of induced tracks, $\boldsymbol{\rho}_{\mathrm{m}}=$ track density on CN-5 glass detector $\left(\times 10^{5} / \mathrm{cm}^{2}\right), \mathbf{P}\left(\chi^{2}\right)=$ probability of obtaining Chi-square value for the given degree of freedom $(\mathrm{n}-1)$. Ages are calculated by using pool statistics and two $\zeta$-values $(262 \pm 38)$ a/cm ${ }^{2}$ for the Thetis reactor, Institute for Nuclear Sciences, Gent University, Belgium (a) and (280 \pm 15$) \mathrm{a} / \mathrm{cm}^{2}$ for experimental reactor of the Institut für Radiochemie, TU München, Garching, Germany (b) (J. Filip). 
obtained for another tinguaite dyke (sample $\mathrm{PH}-3 / 1$ in Ulrych et al. 2006), the young age of which cannot be explained by the effect described by Balogh et al. (2005) but suggests a secondary heating and/or hydrothermal effect in the study area - see below.

\subsection{Fission track data}

According to their crystal chemistry, hydroxylapatites $\left(\mathrm{OH}-\mathrm{F}-\mathrm{SO}_{3}\right.$ types) prevail in the volcanic rocks studied: monzodiorite (A-11), hornblendite (A-9), tephrite (A-4), nephelinite (A-13) and olivine melilitolite (A-27). Fluorapatite $\left(\mathrm{F}-\mathrm{SO}_{3}\right.$ type $)$ is present in the trachyte breccia (A-3) only.

In the analysed set of subvolcanic/volcanic rocks, the apparent fission track ages for apatites are rarely consistent with the K-Ar ages of their parental rocks (with the exception of A-4 and A-10; see Tab. 2 and Fig. 2). Instead, they are typically strikingly younger, postdating the K-Ar ages by c. 5-43 Ma. They cluster into two groups:

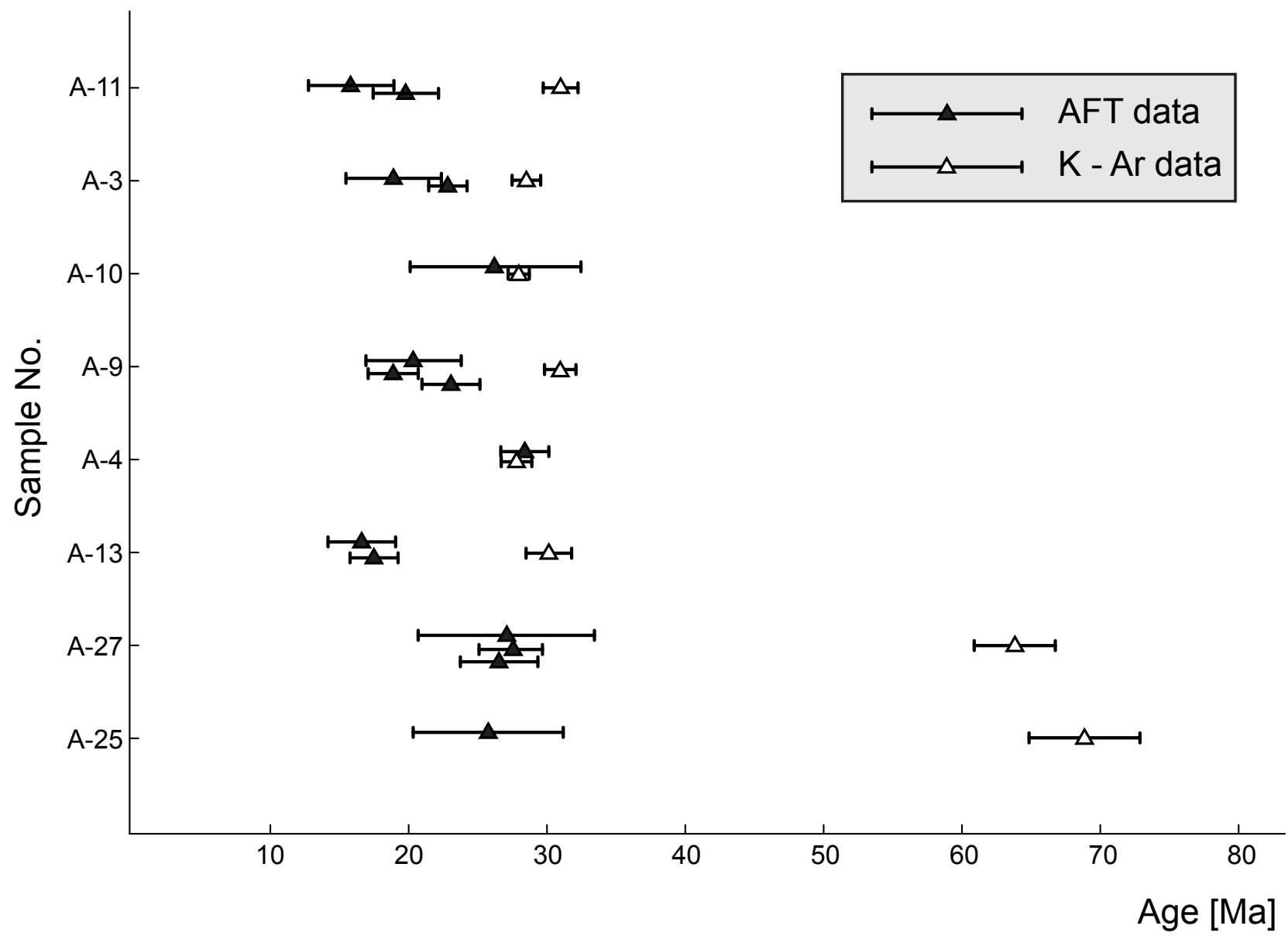

- 28 to 26 Ma, characteristic of pegmatoids in ultramafic alkaline rocks of the Osečná Complex (A-27) at the intersection of the Ohře Rift and the Elbe Zone structures, and similar rocks from the Dvůr Králové nad Labem Complex (A-25) in NE Bohemia, within the Elbe Zone. The same age was detected for apatites from the tephrite flow (A-4) in the České středohoří Mts.

- 20 to 16 Ma, generally determined for rocks of the Ohře Rift region: a trachyte breccia vent fill (A-3), a hornblendite xenolith (A-9) from a subvolcanic sodalite syenite body, and a monzodiorite subvolcanic intrusion (A-11) all from the Roztoky Intrusive Centre of the České středohoří Mts. In addition, they were obtained from a nephelinite intrusion (A-13) in Slaný, about $25 \mathrm{~km}$ SE from the Ohře Rift graben.

Without confined track length measurements and T-t modelling, the AFT ages must be considered only as apparent ages: they may combine an older formation age and a younger mild reset. This fact should be taken into account especially in areas with complex thermal history

Fig. 2 A diagrammatic comparison of the obtained K-Ar ages and pooled AFT ages for the individual samples. The error bars are \pm 1 sigma. 
and high recent thermal flux, like the Ohře Rift graben. The fission track data were therefore statistically checked whether they fit the Poisson distribution. Samples A-27, A-25, A-11, A-10 and A-9 passed the $\chi^{2}$ test, with the individual grains showing only random $\rho_{\mathrm{s}} / \rho_{\mathrm{i}}$ variation governed by the Poisson statistics. This implies that these samples probably did not undergo secondary heating after the primary total annealing and the apparent ages reflect the emergence from the total annealing zone.

Some variation in AFT ages was observed in samples A-9 and A-11 irradiated in two different reactors. The values for each sample, however, overlap with their $1 \sigma$ errors: this makes them eligible for use in this study. The upper limit of $1 \sigma$ error in AFT age of sample A-4 slightly exceeds the K-Ar age of the same sample. This fact does not result from mixing with foreign apatite crystals as no apatite-bearing xenoliths were observed in the rock. It rather suggests that the K-Ar and AFT ages are very close and the magmatic body must have cooled fast and must have been subjected to no thermal alteration later. This is in line with geological evidence (a lava flow).

\section{Discussion}

Discrepancies between K-Ar ages and AFT ages are traditionally attributed to slow cooling rates of the intrusive rock (Hasebe and Hoshino 2003) or to prolonged residence time at depths within the total annealing zone (Oikava et al. 2006). Neither of these explanations is appropriate in this case. Very high cooling rates must be expected for the studied magmatic bodies: they represent sheet-like intrusions several metres to tens of metres thick (A-9, A-10, A-13, A-25), lopolith bodies at maximum tens of metres in thickness (A-27), marginal parts of stocks $\sim 1 \mathrm{~km}$ in diameter (A-11) or lava flows (A-4). As suggested by the geological position and the absence of mineral recrystallization in the host sediments beyond the contact aureole, the maximum emplacement/burial depths can be estimated at several hundred metres (A-27), well above the $120^{\circ} \mathrm{C}$ isotherm.

A more likely explanation is the resetting of the fission track ages in apatites due to the invasion of hydrothermal fluids $\left(\mathrm{T}>100^{\circ} \mathrm{C}\right)$ some time after the rock emplacement and cooling. The two clusters of fission track ages would imply two episodes of hydrothermal fluid reactivation in this part of the Bohemian Massif: in Late Oligocene (28 to $26 \mathrm{Ma}$ ) and Early Miocene (20 to $16 \mathrm{Ma}$ ) times. The thermal event at 28-26 Ma, likely connected with the Oligocene volcanic activity, was sufficiently intense to overprint the Late Cretaceous-Palaeocene ages of the pre-rift volcanics (samples A-25 and A-27). The Oligocene AFT ages of products of syn-rift volcanism were mostly, but not exclusively, reset by the 20-16 Ma event.
For the studied localities, such an assumption is supported by:

1. The presence of highly permeable sediments around the sampled subvolcanic bodies. All bodies are hosted by psammitic sediments of the Bohemian Cretaceous Basin, and are underlain by Permo-Carboniferous detrital sedimentary rocks (A-13) or directly overlie marginal faults of Permo-Carboniferous basins (A-3 and A-11?, A-4, A-25, A-27). These sedimentary basins could have supplied water for fluid circulation. The only body hosted by a less permeable volcanic rock is the camptonite dyke at Dobkovice (A-10), which however shows no discrepancy between K-Ar and AFT datings;

2. The existence of suitable ascent paths near the subvolcanic bodies. The two oldest rocks are spatially associated with the faults of the Elbe Zone: the Zvičina Fault (A-25) and the Lusatian Fault (A-27), see Ulrych et al. (1996) and Pivec et al. (1998a), respectively. Rocks in the Roztoky Intrusive Centre (A-3, A-9, A-10, A-11) were emplaced along faults pertaining to the Ohře Rift graben, later offset by transverse structures (Cajz et al. 2004), for instance the Zubrnice Fault. The Dubičná lava flow (A4) occurs close to the SE marginal fault of the Ohře Rift graben, at its intersection with a transverse fault. Similar is the situation at Slaný (A-13), where the graben-parallel Kladno Fault is dislocated by post-Cretaceous transverse faults (striking NW-SE) with recent saline water issues, $\mathrm{CO}_{2}$ emanations, and a natural gas accumulation (Cílek 1971). Contacts of the subvolcanic bodies with the host rock are also ideal ascent paths for hydrothermal fluids, as suggested by the ubiquitous near-contact kaolinization and ferruginization. The Roztoky monzodiorite body (A11) hosts sulphidic $\mathrm{Pb}-\mathrm{Zn}(\mathrm{Ag}, \mathrm{Te})$ vein mineralization and, at the contact with the surrounding Upper Turonian marlstones, a disseminated pyrite mineralization (Pivec et al. 1998b). Extensive late to post-magmatic hydrothermal alteration (particularly phlogopitization) was reported from olivine melilitolite at Osečná (A-27; Pivec et al. 1998b), clinopyroxenite near Dvůr Králové nad Labem (A-25; Ulrych et al. 1996) and monzodiorite from Roztoky (A-11; Ulrych and Balogh 2000).

3 . The proximity of heat sources near the studied subvolcanic bodies at times of the supposed fluid activation. Later magmatic activity could have contributed heat for the generation of hydrothermal fluids. Bodies of basaltic and phonolitic rocks dated at 28-25 Ma are common along the Lusatian Fault (e.g., Kaiser and Pilot 1986). The large phonolite mass at Olešnice, dated at $17 \mathrm{Ma}$ (Shrbený 1969), could have functioned as a local heat source for hydrothermal fluids in the Roztoky Intrusive Centre.

The idea that the fission track ages reported in the current work could have resulted from hydrothermal fluid activation along major fault systems can be further 
checked against the regional tectonic stresses inferred from intrusive geometries and tectonic observations by Adamovič and Coubal (1999). The period between 30 and $26 \mathrm{Ma}$ was dominated by N-S to NW-SE maximum principal stresses. This arrangement was favourable for the opening of paths (faults, joints) parallel to the Elbe Zone. In the Ohře Rift graben, only transverse structures remained open in this period. This would explain the presence of Late Oligocene AFT ages in the Elbe Zone and their almost complete absence in the Ohře Rift. The period between 24 and 16 Ma was governed by NE-SW maximum principal stress (Adamovič and Coubal 1999) associated with the accelerating subsidence of the Ohře Rift graben. Such process must have mobilized large volumes of fluids along faults parallel to the graben axis. Where combined with elevated heat flux from cooling magma intrusions, the released fluids may have rejuvenated the fission track ages to yield the herein encountered Early Miocene AFT ages.

Hydrothermal activity reflected by AFT ages of sample A-3 from a tinguaite dyke (22.8 and 19.2 Ma) would explain the partial argon loss suspected from unusually low K-Ar ages of some tinguaite dykes at Skrytín. This way, the AFT dating may assist in the interpretation of $\mathrm{K}-\mathrm{Ar}$ ages. It should be noted that the Miocene thermal episode did not reduce the K-Ar age of any of the minerals measured, including analcime.

Samples A-25 and A-27 show very wide differences between their K-Ar and AFT ages. The presented K-Ar ages are well constrained and compatible with the geological setting. Reliability of the AFT ages was confirmed by their passing the $\chi^{2}$ test. The Osečná lopolith and the Dvưr Králové sill can be therefore taken as examples of subvolcanic bodies re-heated long after their emplacement.

\section{Conclusions}

The apatite fission track ages identified for the Late Cretaceous-Paleogene subvolcanic/volcanic rocks of the Bohemian Massif only rarely conform with the K-Ar ages determined for the same. This can be most readily explained by the later heating to temperatures above $\sim 120$ ${ }^{\circ} \mathrm{C}$ during episodes of hydrothermal fluid flow. Two such events can be identified in the post-Cretaceous history of this part of the Bohemian Massif: in Late Oligocene (28 to $26 \mathrm{Ma}$ ) and Early Miocene (20 to $16 \mathrm{Ma}$ ) times. The older episode was detected particularly in the region of the Elbe Zone in NE Bohemia and was associated with the opening of fluid paths during a NE-SW to E-W extension (a crustal release following the Pyrenean phase of Bergerat 1987). Fluid flow along transverse faults of the Ohře Rift graben cannot be excluded. The younger episode seems to have been limited to the Ohře Rift re- gion and governed by the prominent NW-SE extension characteristic of this region. Episodes of hydrothermal fluid activation in the northern part of the Bohemian Massif occurred on the background of prominent brittle crustal deformation, fluid release from compacted porous sediments, emplacement of magma as a heat source, and a favourable regional stress field.

Acknowledgements This research was supported by the Grant Agency of the Academy of Sciences of the Czech Republic (AS CR), Project No. A3013403, and conducted within the Research Plan of the Institute of Geology AS CR, v.v.i., CEZ: AV0Z30130516. The K-Ar dating was supported by OTKA projects No. T060965 and M41434 to $\mathrm{K}$. Balogh. We are indebted to A. Langrová from Institute of Geology AS CR in Prague for microprobe apatite data. The paper benefited from the discussion with E. Hejl of the Institut für Geologie und Paläontologie, Universität Salzburg. The manuscript was considerably improved following the reviews by I. Broska and an unknown reviewer.

\section{References}

Adamovič J, Coubal M (1999) Intrusive geometries and Cenozoic stress history of the northern part of the Bohemian Massif. Geolines 9: 5-14

BALOGH K (1985) K-Ar dating of Neogene volcanic activity in Hungary: experimental technique, experiences and methods of chronological studies. MS ATOMKI Rep D/1: 277-288

Balogh K, Itaya T, Németh K, Martin U, Wijbrans J, Thanh NX (2005) Study of controversial K/Ar and ${ }^{40} \mathrm{Ar} /{ }^{39} \mathrm{Ar}$ ages of the Pliocene alkali basalt of Hegyestü, Balaton Highland, Hungary: a progress report. Miner Slov 37: 298-300

Bergerat F (1987) Stress fields in the European Platform at the time of Africa-Eurasia collision. Tectonics 5: 99-132

Cajz V, Adamovič J, Rapprich V, Valigurský L (2004) Newly identified faults inside the volcanic complex of the České středohoří Mts., Ohře/Eger Graben, North Bohemia. Acta Geodyn Geomater 134: 213-222

Cajz V, Vokurka K, Balogh K, Lang M, Ulrych J (1999) The České středohoří Mts.: volcanostratigraphy and geochemistry. Geolines 9: 21-28

Cílek V (1971) New data on gas and gas-charged waters in the Slaný depression. Sbor geol Věd, Hydrog Inž Geol 8: 67-95 (in Czech with English summary)

Dèzes P, Schmid SM, Ziegler PA (2004) Evolution of the European Cenozoic Rift System: interaction of the Alpine and Pyrenean orogens with their foreland lithosphere. Tectonophysics 389: 1-33 
Apatite fission track implications for timing of hydrothermal fluid flow

DunKL I (2002) TRACKKEY: a Windows program for calculation and graphical presentation of fission track data. Comp and Geosci 28: 3-12

FILIP J (2001) Apatite fission-track analysis method and its applications to thermochronology. Unpublished $\mathrm{PhD}$ thesis, Institute of Geology AS CR, Prague, pp 1-94 (in Czech)

Gleadow AJW, Duddy YR, Green PF, Lovering JF (1986) Confined fission track lengths in apatite: a diagnostic tool for thermal history. Contrib Mineral Petrol 94: 405-415

Hasebe N, Hoshino H (2003) Igneous rock emplacement and exhumation of sedimentary basement; fission track age determination on the Osuzuyama volcano/plutonic complex and surrounding rocks, Miyazaki Prefecture, southwest Japan. Geochem J 37: 537-543

Hurford AJ, GreEn PF (1982) A user's guide to fission-track dating calibration. Earth Planet Sci Lett 59: 343-354

Hurford AJ, Green PF (1983) The Zeta age calibration of fission-track dating. Chem Geol 31: 285-317

Kaiser G, Pilot J (1986) Weiter K-Ar Datierung an jungen Vulkaniten. Z Geol Wiss 14: 121-124

Novák JK, MatĚJKa D (1999) Apatite enrichment in nephelinite from Slánská hora Hill, Central Bohemia. Geolines 9: 104-109

Odin GS, Adams CJ, Armstrong RL, Bagdasaryan GP, Baksi AK, BALOGH K, BARnes IL, BoElriJK NALM, BONAdONNA FP, Bonhomme MG, Cassignol C, Chanin L, Gillot PY, Gledhill A, Govindaraju K, Harakal R, Harre W, HebeDA EH, Hunziker JC, Ingamells CO, Kawashita K, Kiss E, Kreutzer H, Long LE, McDougall I, McDowell F, Mehnert H, Montigny R, Pasteels P, Radicati F, Rex DC, Rundle CC, Savelli C, Sonet J, Welin E, Zimmermann JL (1982) Interlaboratory standards for dating purposes. In: Odin GS (ed) Numerical Dating in Stratigraphy. Wiley \& Sons, Chichester, New York, Brisbane, pp 123-149

Oikava T, Umeda K, Kanazava S, Matsuzaki T (2006) Unusual cooling of the middle Miocene Ichifusayama Granodiorite, Kyushu, Japan. J Mineral Petrol Sci 101: 23-28

Pivec E, Ulrych J, Höhndorf A, Rutšek J (1998a) Melilitic rocks from northern Bohemia: geochemistry and mineralogy. Neu Jb Mineral, Abh 173: 119-154

Pivec E, Ulrych J, Šrein V, Bendl J, Dobeš P, Žák K (1998b) Epithermal Tertiary $\mathrm{Pb}-\mathrm{Zn}-\mathrm{Cu}-(\mathrm{Ag}, \mathrm{Te})$ mineralization in the Roztoky Volcanic Centre, České středohoří Mts., Czech Republic. Geol Carpath 49: 139-146

Řanda Z, Novák JK, Balogh K, Frána J, Kučera J, UlRYCH J (2003) Vinařická hora Hill Cenozoic composite volcano, Central Bohemia: geochemical constraints. Geolines 15: 126-132

Scheck M, Bayer U, Otto V, Lamarche J, Banka D, PhaRAOH T (2002) The Elbe Fault System in North Central Europe - a basement controlled zone of crustal weakness. Tectonophysics 360: 281-299
SHrbenÝ O (1969) Tertiary magmatic differentiation in the central part of the České středohoří Mountains. Čas Mineral Geol 14: 285-298

SiXTA V (1977) Coulometric determinations of carbonates in rock samples. Z Anal Chem 285: 369-372

Ulrych J, Balogh K (2000) Roztoky Intrusive Centre in the České středohoří Mts.: Differentiation, emplacement, distribution, orientation and the age of dyke series. Geol Carpath 51: 383-397

Ulrych J, Pivec E (1997) Age-related contrasting alkaline volcanic series in North Bohemia. Chem Erde 57: 300-323

Ulrych J, Povondra P, Huspeka J, Pivec E, Rutšek J (1990) Chemical composition of melilitic volcanics of northern part of the Bohemian Massif. Unpublished Final Report of Projects II-4-1/07 and II-4-4/05, Faculty of Sciences, Charles University, Prague, pp 1-123 (in Czech)

Ulrych J, Povondra P, Pivec E, Rutšek J, Bendl J, Bilik I (1996) Alkaline ultramafic sill at Dvůr Králové nad Labem, eastern Bohemia: petrological and geochemical constraints. Acta Univ Carol, Geol 40: 53-79

Ulrych J, Pivec E, Langrová A, Jelínek E, Árva-Sós E, HöHndorf A, Bendl J, Randa Z (1998) Geochemically anomalous olivine-poor nephelinite of Ríp Hill, Czech Republic. J Czech Geol Soc 43: 299-331

Ulrych J, Pivec E, Lang M, Balogh K, Kropáček V (1999) Cenozoic intraplate volcanic rock series of the Bohemian Massif: a review. Geolines 9: 123-129

Ulrych J, Svobodová J, Balogh K (2002) The source of Cenozoic volcanism in the České středohoří Mts., Bohemian Massif. Neu Jb Mineral, Abh 177: 133-162

Ulrych J, Novák JK, Lang M, Balogh K, Hegner E, Řanda Z (2006) Petrology and geochemistry and K-Ar ages for Cenozoic tinguaites from the Ohře-Eger Rift (NW Bohemia). Neu Jb Mineral, Abh 183: 41-46

Ulrych J, Dostal J, Hegner E, Balogh K, Ackerman L (in print): Late Cretaceous to Paleocene melilitic rocks of the Ohře/Eger Rift in northern Bohemia, Czech Republic: Insights into the initial stages of continental rifting. Lithos, doi: 10.1016/j.lithos.2007.07.012

Wagner GA, VAn DEN hAute P (1992) Fission-Track Dating. Ferdinand Enke Verlag, Stuttgart, 1-285

Wilson M, Downes H (1991) Tertiary-Quaternary extension-related alkaline magmatism in Western and Central Europe. J Petrol 32: 811-850

WimmenAuER W (1974) The alkaline province of central Europe and France. In: Sørensen H (ed) The Alkaline Rocks. Wiley \& Sons, London, New York, Sydney, Toronto, pp 238-274

ZiEGLER PA (1982) Geological Atlas of Western and Central Europe. Elsevier, Amsterdam, pp 1-130

Ziegler PA, Cloethingh S, van Wees JD (1995) Dynamics of intra-plate compressional deformation: the Alpine foreland and other examples. Tectonophysics 252: 7-59 


\section{Využití metody fission track při datování aktivity hydrotermálních fluid v terciérních vulka- nitech Českého masívu}

Pro soubor svrchnokřídových až paleogénních subvulkanitů a vulkanitů Českého masivu bylo provedeno datování fission track na apatitech (AFT) a K-Ar datování. Nápadné rozdíly mezi stářím zjištěným AFT a K-Ar u většiny vzorků nemohou být vysvětleny nízkou rychlostí chladnutí, protože jde o mělká subvulkanická tělesa malých rozměrů. Na základě získaných výsledků lze naopak soudit, že apatity z těchto hornin znovu vstoupily do zóny úplného vyžíhání během epizod aktivace hydrotermálních fluid podél hlavních zlomových pásem a žilných kontaktů. Z dostupných dat lze usuzovat na dvě takové události: ve svrchním oligocénu (28 až 26 Ma) a ve spodním miocénu (20 až $16 \mathrm{Ma}$ ). Starší událost se projevuje v oblasti oháreckého riftu a labské zóny, zatímco mladší se zdá být omezena na oblast oháreckého riftu. Aktivace hydrotermálních fluid je předurčena zónami oslabení zemské kůry, distribucí center magmatické aktivity a existencí př́hodného regionálního tektonického napět’ového pole. 